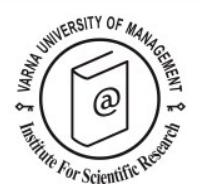

\title{
The impact of social tourism for seniors on the economic development of tourism destinations
}

\author{
Celeste Eusébio $^{1 *}$, Maria João Carneiro ${ }^{2}$, Elisabeth Kastenholz ${ }^{3}$ and \\ Helena Alvelos ${ }^{4}$
}

Received: 15/08/2014 Accepted: 02/08/2015

\footnotetext{
${ }^{1}$ GOVCOPP Research Unit, Department of Economics, Management and Industrial Engineering, University of Aveiro, Campus Universitário de Santiago, 3810-193 Aveiro, Portugal; phone: +351-234-370371; fax: 00351234-370215; e-mail: celeste.eusebio@ua.pt

${ }^{2}$ University of Aveiro, GOVCOPP Research Unit (mjcarneiro@ua.pt)

${ }^{3}$ University of Aveiro, GOVCOPP Research Unit (elisabethk@ua.pt)

${ }^{4}$ University of Aveiro, CIDMA Research Unit (helena.alvelos@ua.pt)

* Corresponding author
}

\section{Abstract}

This paper suggests a framework for assessing the economic relevance of social tourism programmes for tourism destinations, based on two simultaneous approaches: an analysis of the stakeholders' perceptions of the economic impacts and a quantitative assessment of the impacts on the national economy. This framework was applied to a Portuguese social tourism programme directed at the senior market. A survey of supply agents $(\mathrm{N}=220)$ was carried out to analyse the stakeholders' perceptions of the Programme impacts. An integrated model, including a senior survey $(\mathrm{N}=1000)$ and an input-output model, was used to estimate the total economic impact of the Programme on output, household income, employment and Value-added. The supply agents surveyed perceived considerable positive impacts of the Programme on their companies regarding profitability, employment, occupancy rate in the low season, loyalty and attraction of new consumers. They also perceived important positive impacts on local communities regarding decrease of seasonality, diversification and revitalization of local economy. The quantitative assessment also revealed high total economic impacts (direct, indirect and induced) of the Programme on the national economy. Finally, some suggestions to maximize the economic benefits of social tourism programmes for tourism destinations are presented.

(C) 2016 Varna University of Management. All rights reserved

Keywords: Social tourism, economic impacts, input-output models, perceptions of impacts, senior market.

Citation: Eusébio C., M.Carneiro, E. Kastenholz and H. Alvelos (2016) The impact of social tourism for seniors on the economic development of tourism destinations. European Journal of Tourism Research 12, pp. 5-24

\section{Introduction}

Tourism is a major industry worldwide, but there are still many persons with no access to this activity. The senior population in many countries is still relatively underrepresented in the overall tourism market, as a result of 
lacking prior travel experience, low incomes, relative social isolation and/ or poor health conditions. However, particularly this actually growing demographic group could benefit largely from tourism given its social, cultural and health related benefits reported in several studies (Dann, 2002; McCabe \& Johnson, 2013). Social tourism programmes directed to the senior population may help overcome some barriers and stimulate this group's participation in tourism activities.

Several international organizations (e.g International Bureau of Social Tourism - BITS, European Commission) and researchers (e.g. Bélanger \& Jolin, 2011; Minnaert, Maitland \& Miller, 2011), recognize social tourism as an important activity worldwide (Eusébio, Carneiro, Kastenholz \& Alvelos, 2013a), for both participants and society. This kind of initiatives may also have an important role in the economic development of tourism destinations, creating jobs, generating income, diversifying local economic structure and decreasing seasonality. However, doubts persist about the real impact of these initiatives on tourism destinations, since studies in this area are scarce, with almost an absence of strong empirical evidence revealing the scope of these impacts. Moreover, studies on the economic impacts of tourism have adopted only one approach for assessing these: mathematical models to quantify the total economic impacts or analysis of stakeholders' perceptions of impacts.

In order to fill the above mentioned gaps, this paper presents some empirical evidences that highlight the importance of developing social tourism initiatives financed by governments, mainly in periods of economic crises, where usually these initiatives suffer a considerable decrease of public funds. Moreover, the paper intends to develop and test a framework to analyse the role of social tourism for seniors in the economic development of tourism destinations. For this purpose, two complementary approaches to assess the economic impacts of a Portuguese social tourism programme for the senior market Programa Turismo Sénior -, promoted by the INATEL Foundation are adopted. First, an analysis of impact perceptions from the tourism supply agents' perspective is presented. Second, a calculation of the program's total economic impacts, based on information on programme costs, participants' expenditures and an input-output model for the Portuguese economy is developed. For assessing the perceptions of tourism suppliers concerning the sectorial and territorial economic impacts of this programme, a survey of organizations affected by it was carried out. In order to quantify the total (direct, indirect and induced) economic benefits of the programme concerning output, employment, household income and valueadded, total expenditures carried out in the programme and respective multiplier effects were calculated. This study differs from conventional tourism research on economic impacts by analysing the economic relevance of a social tourism programme for the senior market through the two aforementioned approaches.

In this paper we start with a conceptual introduction into the topics of social and senior tourism and discuss results from existing studies on the impact of social tourism programs. Then, the methodology of data collection and techniques used to assess the economic relevance of a Portuguese social tourism programme for the senior market are presented. Results, both regarding supply agents' perceptions of the programme's economic impacts and in terms of the total economic impact of the Programme (output, household income, value-added and employment) to the Portuguese economy are presented in the third section. The paper ends with some guidelines for strategies designed to maximize the economic benefits of social tourism for tourism destinations, limitations of the study and suggestions for further researches in this domain.

\section{Literature review}

Social Tourism for Seniors

Although the United Nations (1948) declared the opportunity to enjoy leisure and holidays a human right, there are still many people excluded from tourism for several reasons. Senior travellers deserve, in this context, particular attention, not only since the elderly are frequently constrained from travelling due to economic and health related reasons (BITS 2011; Fleischer \& Pizam, 2002; Nimrod, 2008), 
but also given the fact that it is an increasing demographic group, in which physical disabilities are a common additional constraint (increasing with age), being seniors also frequently affected by social isolation.

However, the classification of who is a "senior tourist" is not consensual, being defined by diverse authors and institutions as a traveller belonging to a population group, beginning "anywhere from 50 up to 65 years of age" (González, Rodríguez, Miranda \& Cervantes, 2009: 179), while some authors discuss the relativity of the concept, suggesting the consideration of cognitive, perceived or felt age rather than simply chronological age (Cleaver \& Muller, 2002; González et al., 2009). Independently of the definition of "senior", as a matter of fact, Europe faces in the near future a number of challenges associated with an ageing society, as a consequence of the postwar baby boom generation reaching retirement age, gradual increase of life expectancy, resulting from an improvement of quality of life standards and healthcare and relatively modest fertility rates simultaneously decreasing the relative share of the younger population (EUROSTAT, 2013). Forecasts (EUROSTAT, 2012) concerning the age structure in 2050 indicate an increase in the number of elderly, with those aged over 65 years expected to account for $27.8 \%$ of the European population and those aged over 80 years $10.1 \%$ in 2050 . Worldwide, the number of people over 60 years is estimated to more than double to constitute $22 \%$ of the world's population by 2050 (Magnus, 2009).

These ageing tendencies are also visible in Portugal where, according to INE (2013: 16), "The weight of the elderly population continued to follow an upward trend, as a consequence of a decline in fertility and an increase in longevity". This is reflected in an ageing ratio that went up from 102.2 (aged 65 and over per 100 young individuals), in 2000, to 131 in 2012 (INE, 2013). Additionally, those aged above 65 are one of the most vulnerable groups in the Portuguese society regarding the risk of poverty, which showed a record in 2011 with a risk-of-poverty rate of $17.4 \%$ (INE, 2013).
Several authors (e.g. Urhausen, 2008; Wang, Cheng, \& Chou, 2007) expect a substantial growth of the senior tourist market in the next decades, not only due to population aging and improvement of health conditions, but also due to the aging of new generations or age cohorts, more used to travelling. Additionally, this group's increasing travel propensity and relatively fewer limitations regarding timing of travel and duration of stay (Nimrod \& Rotem, 2010) implies the opportunity for increasing demand and occupation rates in the low tourist season.

Social tourism programmes play an important role in making tourism accessible to all and in also promoting tourism amongst the senior population. The European Economic and Social Committee (EESC, 2006) suggests social tourism includes all the activities developed by organisations to help those totally or partially inhibited to participate in tourism (e.g. due to low incomes, disability, personal or family isolation, reduced mobility, geographical barriers), in overcoming travel constraints, since tourism is considered a right.

According to Minneart, Maitland and Miller (2007) social tourism provides "an added moral value, which aims to benefit either the host or the visitor in the tourism exchange" (Minnaert et al., 2007: 9), however there are diverse interpretations and implementations of social tourism in diverse countries. Differences may be identified in the level of government support given to social tourism, with some countries (e.g. France; Brazil, Chile; Portugal and Spain) actively boosting the development of social tourism, while others adopt rather noninterventionist approach (Eusébio et al., 2013; McCabe, 2009; Minnaert et al., 2011; Diekman \& McCabe, 2010). In the countries more active in this field, social tourism is frequently implemented as some form of financial or other kind of support to disadvantaged groups enabling them to take a holiday (McCabe, Joldersma \& Li, 2010).

Minnaert et al. (2011: 404-405) distinguish four interpretations of social tourism visible in corresponding schemes existing in Europe, depending on a) the initiative being standardized or specific, and on $b$ ) it being only 
accessible to social tourism users or open to all, resulting in social tourism fitting into:

- the participation model - based on a standardized product, made available via specific schemes to social tourism users;

- the inclusion model - stimulating tourism participation as a universal benefit/ right (e.g. through subsidized schemes such as holiday vouchers in France) through a standardized tourism product for all;

- the adaptation model - product that is specifically adapted to and only directed at respective social tourism participants;

- the stimulation model - a specifically adapted social tourism product, but open to wider groups, aiming at the stimulation of local destination economies.

The Bureau International du Tourisme Social (BITS), distinguishes four major markets of social tourism: families, young people, seniors and persons with disabilities or reduced mobility, which are also the target groups of social tourism identified in the Calypso Programme (Minnaert et al., 2011). The initiatives promoting social tourism amongst the elderly are generally supported by public funding and most of them take the form of lowcost domestic holidays (Minnaert, Maitland, \& Miller, 2009). Examples are organisations such as INATEL, in Portugal, IMSERSO, in Spain and the Brazilian Ministry of Tourism, developing tourism schemes designed for seniors, simultaneously aiming at a stimulating the destination areas' economies, particularly in the low season (Almeida, 2011; Diekmann \& McCabe, 2011; Eusébio et al., 2013a; Minnaert et al., 2011), thereby being classifiable as belonging to the before mentioned adaptation and stimulation model.

However, the current economic climate has inspired the debate in many countries about the State's role in providing social security and public welfare, calling for private stakeholders' more active involvement in solving society's problems and a corresponding reduction of the public welfare budget (Minnaert et al., 2011). Consequently and in face of many other more urgent social concerns, providing tourism opportunities to those typically lacking access requires arguments demonstrating concrete impacts of these programmes justifying investment in times of scarce financial resources. That is why the argument of these schemes falling under the stimulation model and actively enhancing the destination's economy, with evidence of wide ranging economic benefits, is most important to maintain public funding, particularly in times of economic crises, as is the case of Portugal. Given the importance of social tourism in general, and of corresponding schemes directed at seniors in particular, it is also important to measure the several impacts of this kind of initiatives on tourism destinations. The next section presents a theoretical reflection concerning the economic relevance of social tourism programmes for tourism destinations.

Social Tourism Programmes and economic development of tourism destinations

Social tourism programmes play a relevant role both for the well-being of its participants and for economic development of tourism destinations (Carneiro, Eusébio, Kastenholz \& Alvelos, 2013a; Eusébio et al., 2013a; Hazel, 2005; Higgins-Desbiolles, 2006; Minnaert et al., 2011), promoting the development of host communities, through its capacity to attract investment, to generate additional household income, to diversify the local economy structure, create new jobs and increase state revenues. As Minnaert et al. (2011: 410) highlight, social tourism contributes "to social integration, to the creation of sustainable tourism structures, to employment and economic development at the destination level and to the so-called global development by offering an alternative to declining agriculture and manufacturing industries". EESC (2006) also emphasises that social tourism can help combat seasonality and create stable and high quality employment. Additionally, frequently social tourism programmes are implemented in territories characterized by low levels of economic development (Eusébio et al., 2013a; Fontanari \& Kern, 2003) and may have an important role in maintaining the population in these territories.

Despite the relevance of social tourism, empirical evidences about the impact of this kind of tourism on economic development of the destinations where these programmes take 
place is scarce (Eusébio et al., 2013a; Hazel, 2005; Higgins-Desbiolles, 2006; McCabe, 2009; Minnaert et al., 2009). Studies to assess the social tourism programmes' contribution to economic development in host regions are therefore required. One of the few studies published in this field was carried out in 2009 regarding the employment in Social Tourism in Europe. This study was developed under the auspices of EFTA (European Free Trade Association) and BITS (ULB-IGEAT-LITOteS, 2009). Still, there is a lack of knowledge regarding both the stakeholder's perceptions of social tourism programmes' impacts and the quantification of the total economic impact of social tourism programmes worldwide. In order to overcome this gap a study estimating the total economic benefits (output, employment, household income and value-added) of a Portuguese social tourism programme (Programa Saúde e Termalismo Sénior) through an input-output model was published in 2013 (Eusébio et al., 2013a). The results of this study reveal that, despite the limited scope of this programme, involving only about five thousand participants, its total economic impact was substantial. More specifically, in 2007, a total of 15, 350,548 Euros of output, 4,044,834 Euros of household income, 5,379,181 Euros of value-added and 247 jobs were generated in the Portuguese economy in consequence of this social tourism programme (Eusébio et al., 2013a). Another study carried out in the United Kingdom shows that many organizations, which participate in social tourism programmes, highlight the economic benefits of social tourism (All-Party Parliamentary Group on Social Tourism, 2011). In this country, thousands of rooms are left empty in the nonsummer months (high seasonality) leading to decreased tourism employment in these months. Social tourism can help alleviate these problems by allowing disadvantaged groups to have access to holiday accommodation in the low-season, bringing benefits not only to the accommodation providers, but also to the food and beverage, transports, attractions, retail and cultural sectors (All-party Parliamentary Group on Social Tourism, 2011). Also the Calypso Programme, currently being run by the European Commission, stresses the economic benefits of Social Tourism in Europe.
The role of a social tourism programme for the economic development of host communities may be evaluated using several approaches. However, the literature in this field is very limited, with a literature review on tourism's economic impact studies, published in the past four decades, identifying two approaches as the most frequently used: (i) models assessing the host' perceptions of tourism impacts (e.g. Andereck, Valentine, Knopf \& Vogt, 2005; Brunt \& Courtney, 1999; Eusébio \& Carneiro, 2012) and (ii) mathematical models quantifying the total economic impacts of tourism (e.g. Archer, 1995; Bergstrom, Cordell, Ashley \& Watson, 1990; Eusébio et al., 2013b; Frechtling \& Horváth, 1999; Fresenmair, Jones, Um \& Ozuna, 1989; Kumar, 2004; Lichty \& Steines, 1982; Mayen, Muller, Woltering, Arnegger \& Job, 2010).

A limited number of studies analyse the suppliers' perceptions of tourism impacts (e.g. Byrd, Bosley \& Dronbergen, 2009; Hardyam, 2005), being even more limited regarding suppliers' perceptions of economic impacts of a social tourism programme. In this domain, the study carried out by Carneiro, Eusébio, Kastenholz \& Alvelos (2013b) on the suppliers' perceptions of socioeconomic impacts of a Portuguese social tourism programme (Programa Saúde e Termalismo Sénior) stands out. The results of this study reveal that the suppliers perceive positive economic impacts, both on the participant organizations and on local economic development through, for example, an increase of sales and occupation rates, an increase of profitability and a reduction of seasonality.

Regarding the studies that analyse the total economic benefits of tourism, the literature review shows that input-output models have been more frequently used to quantify the multiplier effects (e.g. Archer 1995; Daniels, Norman \& Henry, 2004; Freeman, 1997; Hjerpe \& Kim, 2007; Lee \& Kwon, 1995; West \& Gamage, 1997; Eusébio, Castro \& Costa, 2013b). Several authors (e.g. Baaijens, Nijkamp \& Montfort, 1998; Eusébio et al., 2013b; Frechtling \& Horváth, 1999; Archer, 1995) emphasise the relevance of input-output models to quantify the economic impacts, providing a very detailed understanding of 
economic impacts. Indeed, this kind of models permits a separate estimation of the primary (direct effects) and secondary effects (indirect and induced) of a change in tourism demand. In order to carry out an input-output model to estimate the total economic impact of a social tourism programme on output, income and employment, two sets of data are required. The first is the final demand broken down into products or industry categories, and the second is a set of multipliers corresponding to these expenditure categories (Fretchling \& Horváth, 1999). More recently, general equilibrium models have been used to study the economic contribution of tourism in several countries (e.g. USA, Australia, Spain, Indonesia and Hawai) (Dwyer, Forsyth \& Spurr, 2005). In Portugal, the available information to construct this type of models is very limited, making the design of a general equilibrium model a very complex task.

\section{Empirical Study}

The empirical study presented in this paper is based on data collected in the scope of a project undertaken in 2009 for the INATEL Foundation. The study's main objective is to assess the economic impact of a social tourism programme for the senior market - the Programa Turismo Sénior -, for the period between 2001 and 2005, promoted by the INATEL Foundation. The next sections present a brief characterisation of the Program, the methodology adopted in the study and a discussion of the results obtained.

\section{Characterization of the Portuguese Social Tourism Programme for senior market}

The Programa Turismo Sénior, started in 1995, is a conjoint initiative of the Ministry of Economy and Innovation and the Ministry of Labour and Social Solidarity, financially subsidized by the Turismo de Portugal, I.P. and the Instituto de Gestão Financeira da Segurança Social (INATEL, 2005). Its development process, as well as its commercialization, implementation and evaluation, are carried out by the INATEL Foundation. This programme is designed to citizens, aged over 60, who can be accompanied by their spouse or by another person aged over 18, if assistance is needed.
The objectives of the Programme can be categorized as social, economic and cultural. At a social level, it aims at giving senior citizens the opportunity of occupying their spare time with tourism trips, at reduced prices and with excellent safety and assistance conditions. At a cultural level, and through the visit of tourism destinations with high historical and cultural interest, the Programme aims at enriching participants' culture. At an economic level, the stimulation of local economic activities must be stressed, in the first place of those connected to tourism, delivering goods and services directly to the senior visitors (lodging, food services, transportation, entertainment and commerce).

The trips included in this Programme have a length of stay of 8 days ( 7 nights) and integrate destinations located in Portugal (mainly) or Spain. Packages include lodging (halfpension), transportation (between the district capital and the accommodation unit), cultural and entertainment activities and permanent monitoring by a recreational assistant.

Regarding the evolution of demand in the period from 2001 to 2005, an increase of number of participants by $12 \%$ is observed (from 47.794 in 2001 to 53.480 in 2005). The available information for the year of 2011 shows that, comparing to 2005 , there was a reduction of about $44 \%$ in the number of participants (which were 29710 in 2011), which is a consequence of the lower government funding of the programme, due to the economic constraints experienced in Portugal in the last years.

\section{Methodology}

In order to analyse the economic relevance of the Portuguese Social tourism Programme for the senior market the methodology presented in Figure 1 was used.

Methodology adopted to analyse the perceptions of tourism suppliers regarding the economic impacts of the Programme

One approach used to evaluate the economic impacts of the Programme was to assess the perceptions of several organizations that participated as suppliers of tourism products in the scope of the Programme - accommodation 


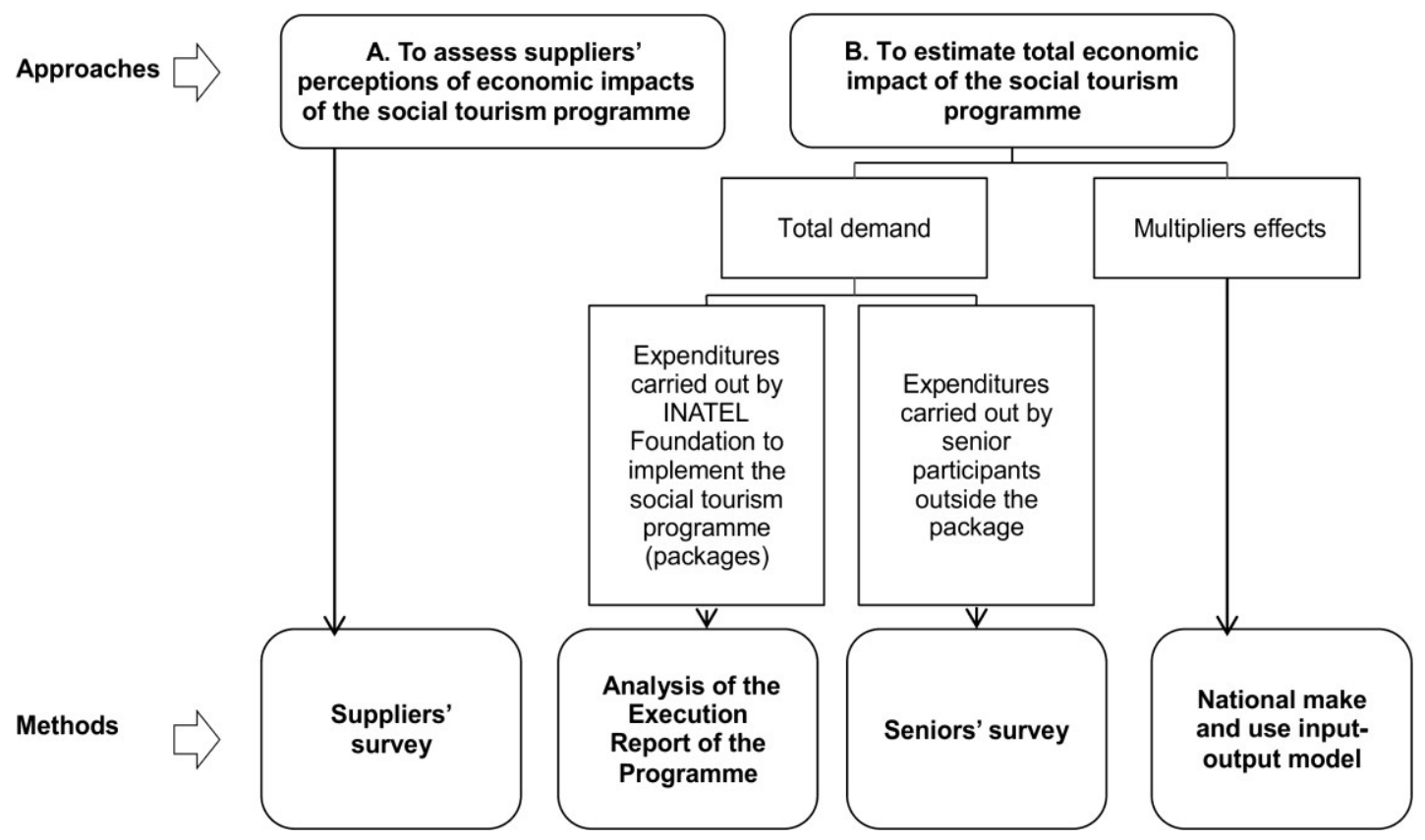

Figure 1. Methodology used to analyse the economic relevance of the Portuguese Social Tourism Programme for Senior Market

units, entertainment companies, restaurants, transportation companies (e.g. bus companies), points of sale (e.g. INATEL's offices and travel agencies) and local shops (e.g. shops selling local products and souvenirs) - through the application of a questionnaire.

The population of tourism suppliers under analysis was composed by all suppliers who provided tourism products to seniors who participated in the Programme between 2001 and 2005. The INATEL Foundation provided the researchers a complete database of all organizations that supplied tourism products in the scope of the Programme in the mentioned period, except for local commerce, whose universe was impossible to determine. All the accommodation units and bus companies who participated in the Programme were surveyed in 2009, yielding a total of responses from 67 accommodation units located in diverse regions of the country (11 holiday centres run by INATEL and 56 private hotel units) and 16 bus companies. However, given the impossibility of surveying all other suppliers participating in the Programme during the period under study, some sampling procedures were adopted to select the other groups. As far as entertainment companies are concerned, a total of 36 companies were surveyed (from a total of 625 entertainment companies participating in the Programme), including the six casinos who participated in the Programme and 30 other entertainment companies selected using a stratified sampling approach based on location and the type of entertainment services provided. A stratified sampling approach based on location was also adopted to identify a sample of restaurants and a sample of points of sale of the Programme resulting in a total of 20 restaurants (from a total of 52 participating restaurants) and of 50 points of sale - INATEL's offices and travel agencies (from a total of 628 points of sale participating in the Programme). Despite the attempts to obtain data from two air companies that were participating in the Programme when the data collection was carried out, only one of them answered the questionnaire. A convenience sampling approach was used to identify 30 local commercial establishments located near the accommodation units, considering that seniors 
would be more likely to go shopping close to the accommodation units.

Accordingly, a total of 220 organizations were surveyed - 67 accommodation units, 36 entertainment companies, 17 transportation companies (16 bus companies and one air company), 50 points of sale of the trips (INATEL's offices and travel agencies), 20 restaurants and 30 local shops.

The questionnaire administered to these tourism suppliers participating in the Programme was designed to assess both the Programme's sectorial and territorial economic impacts, as mentioned above. Therefore, in the questionnaire, first the suppliers were asked to report the perceptions about the impact of the Programme on their own organization regarding: (i) sales or occupancy rates; (ii) employment; (iii) reduction of seasonality; (iv) profitability; (v) quality of infrastructures; and (vi) quality of the services provided. Respondents answered on a five-point scale from 1 "very negative" to 5 "very positive". Then, the tourism suppliers located in the destination territories or that had stronger links with these territories - accommodation units, entertainment companies, restaurants and local commerce - were also asked to indicate their perceptions regarding the impact of the Programme on local communities of the destinations integrated in the Programme. They were asked to indicate their perceptions regarding the impact on: (i) local employment; (ii) quality of tourism supply; (iii) dynamisation of local economy; (iv) diversification of local economic activities; and ( $v$ ) valorisation of regional products, using the above-mentioned five-point scale. Additionally, the suppliers were requested to report their global satisfaction with the Programme in a five-point scale from 1 "very unsatisfied" to 5 "very satisfied" and the probability of applying to the Programme again in a five-point scale from 1 " not likely" to 5 "very likely".

For surveying tourism suppliers, first the researchers contacted the suppliers to explain the objective of the study and then the questionnaire was administered via direct personal administration, by phone, by fax or by mail, according to each supplier's preference.
Collected data was analysed with descriptive statistics for the whole sample and comparisons between the several types of organizations surveyed were carried out with Kruskal-Wallis tests as the assumptions of Anova were not met.

Methodology adopted to quantify the economic impacts of the Programme

To estimate the total economic impacts of a social tourism programme for the senior market it is necessary to quantify the total demand by type of products consumed and the multiplier effects.

\section{Methods to estimate total demand}

Two kinds of expenditures resulted from the implementation of the Portuguese Social Tourism Programme for the senior market: (i) expenditures carried out by INATEL Foundation to implement the programme and (ii) expenditures carried out by seniors participants undertaken outside the package tour.

\section{(i) Expenditures carried out by INATEL} Foundation to implement the programme

These expenditures were estimated based on the Execution Report of the Programme for the year 2005 (INATEL, 2005). In order to supply packages tours to seniors, INATEL Foundation makes expenditures, using public funds and the contributions of the senior participants to purchase the tour, in several economic activities (e.g. accommodation, food and beverage, transportation, cultural, entertainment and sport activities, insurance, travel agencies and financial institutions).

(ii) Expenditures carried out by seniors - survey of the seniors participating in the Programme

One of the approaches used to quantify the economic impact of the Programme was to undertake a survey of seniors, in 2009, who participated in the Programme between 2001 and 2005. A questionnaire was designed to assess the seniors' expenditures beyond their payment of the package tour. Seniors were asked to report the amount of expenditures they made by trip on transportation, food and beverage, entertainment, shopping and other issues, beyond the payment of the package tour. 
Table 1. Sampling approach adopted to select the seniors who were surveyed

\begin{tabular}{|c|c|c|c|c|c|}
\hline \multirow[t]{2}{*}{ Gender } & \multirow[t]{2}{*}{ Age } & \multirow{2}{*}{$\begin{array}{c}\text { Place of } \\
\text { residence } \\
\text { (municipality) }\end{array}$} & \multicolumn{2}{|c|}{ Population } & \multirow{2}{*}{$\begin{array}{c}\text { Sample } \\
\mathrm{N}\end{array}$} \\
\hline & & & $\mathbf{N}$ & $\%$ & \\
\hline \multirow[t]{4}{*}{ Male } & \multirow[t]{2}{*}{60 to 75 years old } & Lisbon and Oporto & 3337 & 11.3 & 114 \\
\hline & & Other & 6940 & 23.5 & 236 \\
\hline & \multirow[t]{2}{*}{ More than 75 years old } & Lisbon and Oporto & 2636 & 8.9 & 90 \\
\hline & & Other & 4427 & 15.0 & 150 \\
\hline \multirow[t]{4}{*}{ Female } & \multirow[t]{2}{*}{60 to 75 years old } & Lisbon and Oporto & 2058 & 7.0 & 70 \\
\hline & & Other & 4782 & 16.2 & 162 \\
\hline & \multirow[t]{2}{*}{ More than 75 years old } & Lisbon and Oporto & 1948 & 6.6 & 66 \\
\hline & & Other & 3345 & 11.3 & 112 \\
\hline \multicolumn{3}{|l|}{ Total } & 29473 & 100.0 & 1000 \\
\hline
\end{tabular}

Given the impossibility of surveying all the seniors who participated in the Programme, a sample was selected from the complete database of seniors provided by the INATEL Foundation, using a stratified sampling approach based on gender, age and place of residence (see Table 1). In total, 1000 seniors were surveyed by phone. Portraying the population, the sample was composed by $59 \%$ males, $58 \%$ seniors aged between 60 and75 years and by $66 \%$ seniors living in municipalities other than Lisbon and Oporto.

\section{Methodology to quantify the multipliers}

The input-output analysis is a widely accepted and useful method (Daniel et al., 2004) to

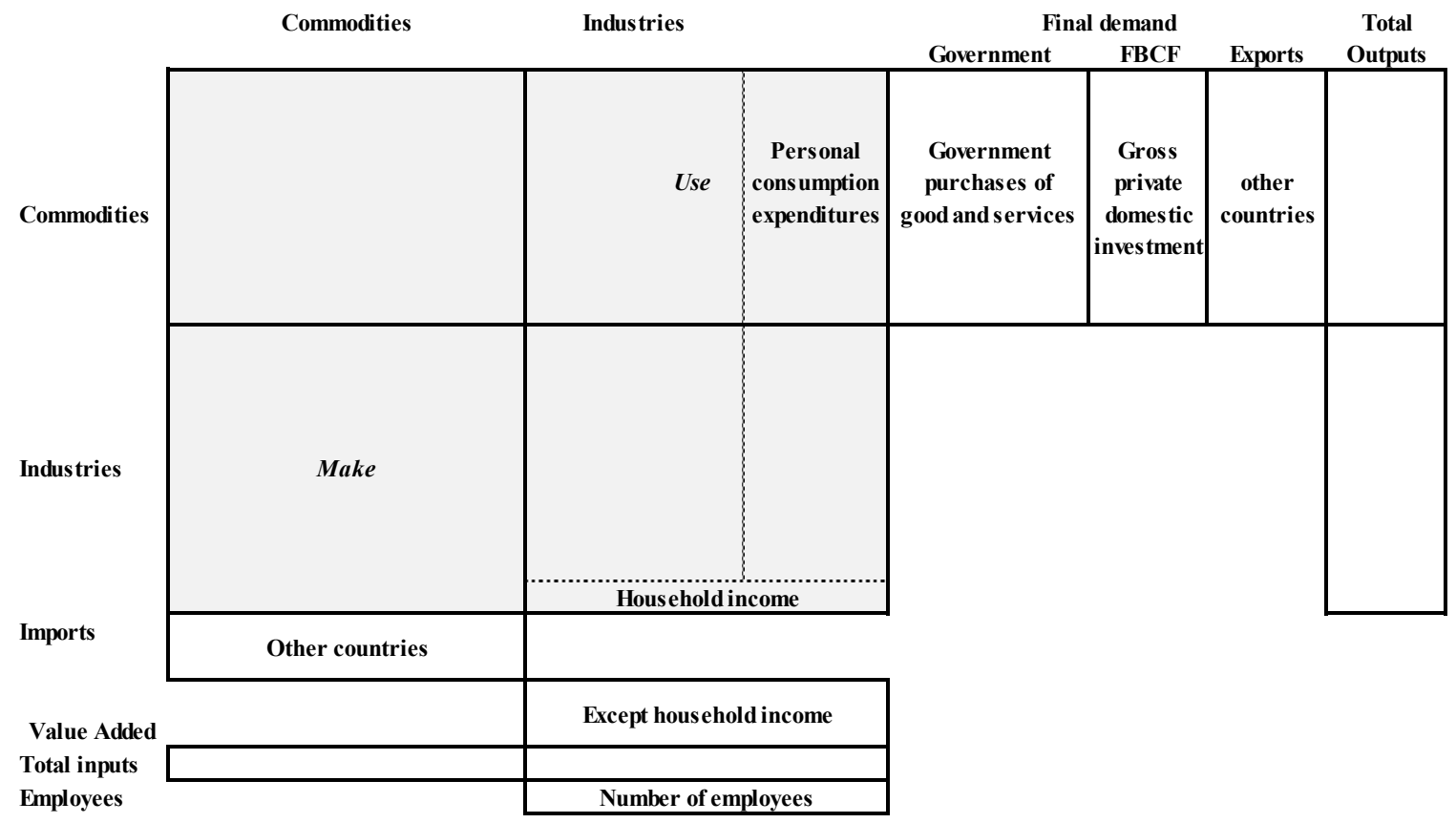

Figure 2. Structure of the input-output matrix used to calculate total multipliers effects Source: Based on Eusébio et al. (2013) 
calculate tourism multiplier effects, therefore chosen here to quantify the multipliers effects of the social tourism programme under analysis. The vectors of expenditures generated by the social tourism programme for seniors were incorporated into a national make and use input-output model developed for this specific study. A make and use input-output matrix (31 industries by 31 products) was created based on the last make and use matrixes published by the National Statistical Institute of Portugal (INE, 2007). The date on which the study was conducted this was the input-output matrix, published by the National Statistics Institute, with definitive data.

In order to quantify the total effects (direct, indirect and induced) of the social tourism programme, two kinds of input-output models were developed. First, an open make and use input-output model was developed to quantify direct and indirect effects. Second, a closed input-output model, including the household sector as one of the processing sectors, was created, based on an input-output table with the structure of the table presented in the Figure 2, to quantify total Keynesian multipliers (output, household income, value-added and employment), as indicated in the Figure 3

In this research the Keynesian multipliers, also designed in the literature as "normal" multipliers, were used. As suggested by Liu et al. (1984) these multipliers, when compared with the ratio multipliers, are a better measure of the overall impacts generated by tourism expenditures. The Keynesian multipliers represents the amount of income or of other economic variable generated per unit of tourism expenditure, while the ratio multipliers give only the extent of secondary effects generated relative to the direct effect obtained (Eusébio et al., 2013).

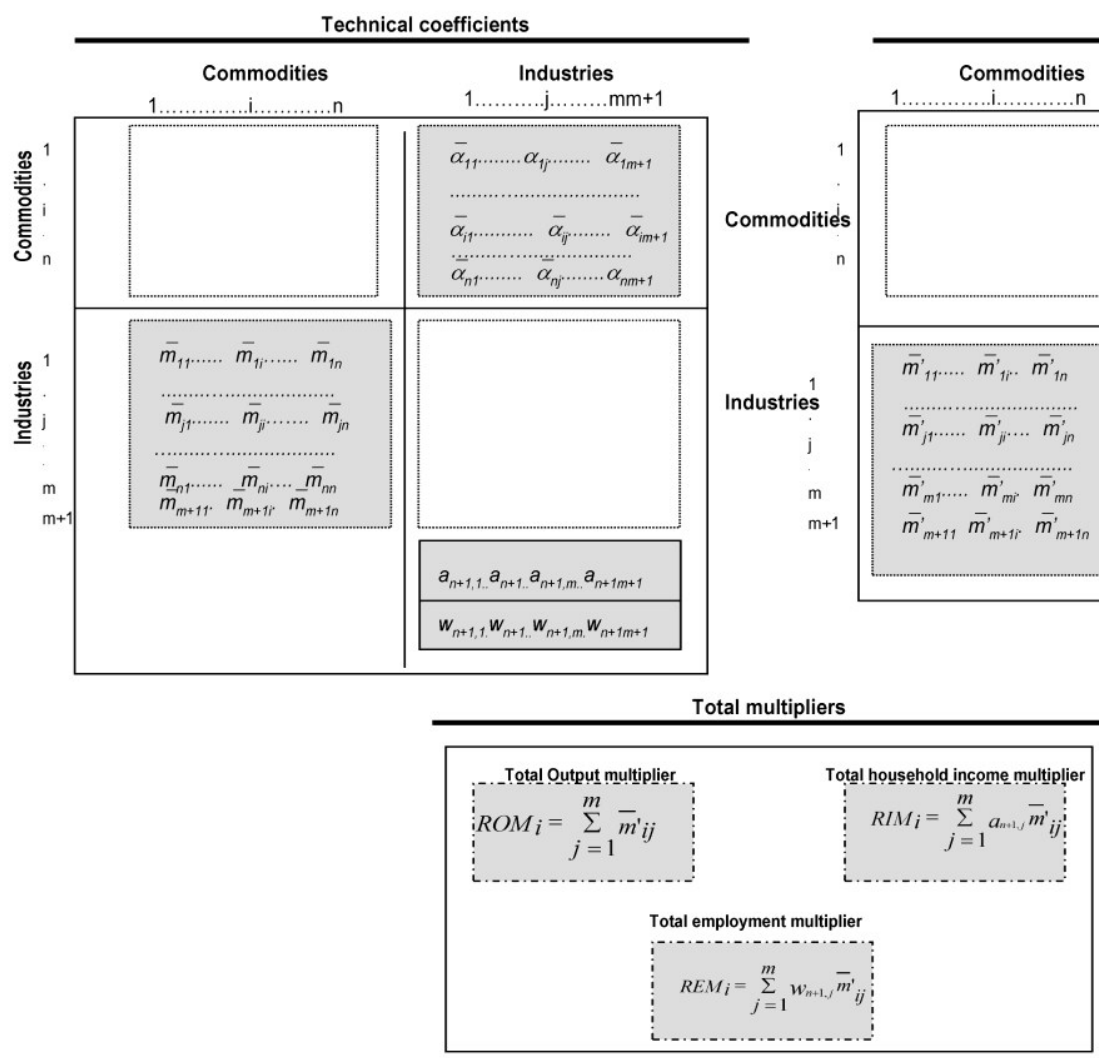

Figure 3. Structure of the input-output model used to quantify total Keynesian multipliers Source: Eusébio et al. (2013) 


\section{Results and discussion}

Tourism suppliers' perceptions of economic impacts

Globally, the tourism suppliers surveyed consider that the Programme has positive economic impacts on their own organization and on the local community where the organization is located (Table 2). The major positive impacts of the Programme on the suppliers' organization seem to be the increase of sales or occupation rates (average value of 3.73 in a scale of 1 "very negative" to 5 "very positive"), followed by the reduction of seasonality (3.66) and the increase of profitability (3.55). The suppliers perceive even higher positive economic impacts on the local community where their organization is located, particularly regarding the valorisation of regional products (4.21 in the scale referred above), the improvement of the quality of local tourism supply (4.15) and the dynamisation of local economy (4.00).

Although, the suppliers recognize the positive impacts of the Programme, results reveal statistically significant differences regarding the perceptions of the different types of stakeholders. Although these differences are especially high in the case of some impacts at the level of the organization - reduction of seasonality, improvement of the quality of equipment and infrastructure and increase of employment - significant differences are noticed in all the impacts except for generation of local employment.

The managers of accommodation units, restaurants and transportation companies are those who perceive higher benefits of the Programme in their organization. This probably happens because these companies are the major beneficiaries of the Programme, considering the amount of money spent on the different tourism products.

On the other hand, the managers of entertainment companies and restaurants are those perceiving more benefits of the Programme to the local community. This may be due to the more family-run type of these companies, with more managers from the local community responding here. . The reduced size of these companies and their greater integration in the local community may contribute to the perception of more benefits of the Programme to that community.

Analysing the overall sample of suppliers, one may conclude that suppliers are highly satisfied with the Programme (with an average value of 3.84 in a scale of 1 "very dissatisfied" to 5 "very satisfied") and have a high probability of repeating participation in the Programme (an average of 4.10 in a scale of 1 "not likely" to 5 "very likely"). Nevertheless, statistically significant differences are also detected among the different types of suppliers in this context. The suppliers who are most satisfied with the Programme are those recognizing the highest impact of the Programme on local community the entertainment companies and the restaurants. The diversity of answers is extremely high regarding the probability of repeating participation in the Programme (std. deviation=1.591), with the entertainment and transportation companies being highly interested in repeating $(4.82$ and 4.73 , respectively), whereas accommodation units are those with a lower probability of applying again (3.02).

\section{Estimation of total economic benefits to the national economy}

\section{Expenditures}

Table 3 presents the expenditures carried out in the Portuguese economy in the scope of the Social Tourism Programme for the senior market. In 2005, 16,497,872 Euros were generated in the Portuguese economy as a consequence of this social tourism Programme. Expenditures carried out by the INATEL Foundation for implementing this Programme correspond to $80 \%$ of total expenditures generated, while the expenditures carried out by seniors "extra-package" represent $20 \%$ of the total. Moreover, various economic activities directly benefit from the Programme. Hotels and restaurants (55.25\% of total expenditures), transports and travel agencies (26.72\%) and retail trade $(10.73 \%)$ being the most benefited economic activities.

The results obtained in the seniors' survey (Table 3) reveal that the majority of the expenditures carried out extra-package correspond to shopping (54.4\%). The expendi- 


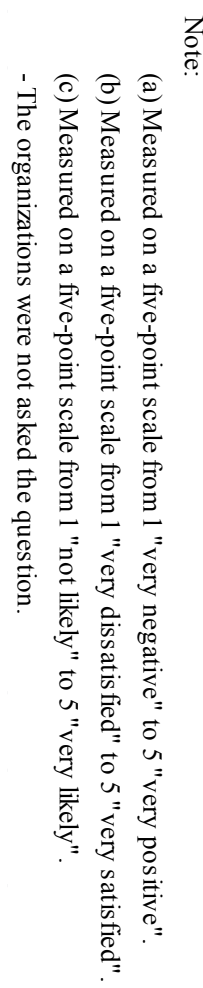

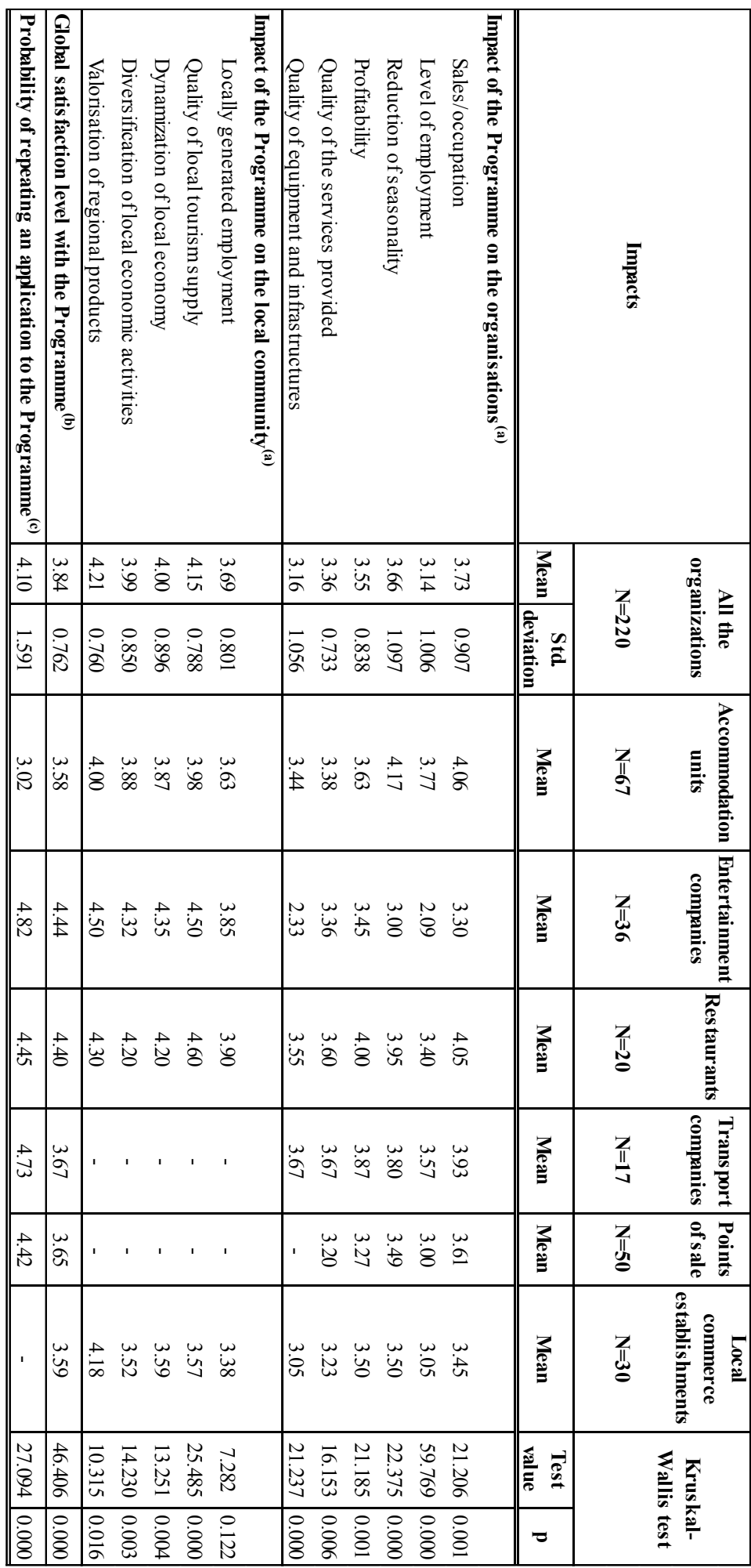

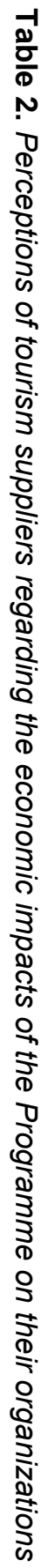


Table 3. Total expenditures of the Portuguese Social Tourism Programme for the senior market

\begin{tabular}{|c|c|c|c|c|c|c|c|}
\hline \multirow[t]{2}{*}{ Economic Activities $^{a}$} & \multirow[t]{2}{*}{ Types of goods and services } & \multicolumn{2}{|c|}{$\begin{array}{l}\text { Total expenditures } \\
\text { generated to } \\
\text { implement the } \\
\text { programme }\end{array}$} & \multicolumn{2}{|c|}{$\begin{array}{l}\text { Extra-programme } \\
\text { expenditures carried } \\
\text { out by seniors }\end{array}$} & \multicolumn{2}{|c|}{ Total expenditures } \\
\hline & & $€$ & $\%$ & $€$ & $\%$ & $€$ & $\%$ \\
\hline $\begin{array}{l}\text { G- Wholesale and retail trade } \\
\text { repair of motor vehicles, } \\
\text { motorcycles personal and } \\
\text { household goods }\end{array}$ & Shopping & - & - & $1,770,254$ & $54.40 \%$ & $1,770,254$ & $10.73 \%$ \\
\hline \multirow[b]{2}{*}{ H-Hotels and restaurants } & Accommodation services & $7,498,462$ & $56.62 \%$ & - & - & $7,498,462$ & $45.45 \%$ \\
\hline & Food \& Beverages services & 492,386 & $3.72 \%$ & $1,124,260$ & $34.55 \%$ & $1,616,646$ & $9.80 \%$ \\
\hline \multirow{3}{*}{$\begin{array}{l}\text { I - Transport, storage and } \\
\text { communication }\end{array}$} & Passenger transportation on road & $2,341,234$ & $17.68 \%$ & 62,331 & $1.92 \%$ & $2,403,565$ & $14.57 \%$ \\
\hline & Air transport & $1,218,286$ & $9.20 \%$ & - & - & $1,218,286$ & $7.38 \%$ \\
\hline & Services of travel and tourism agencies & 786,574 & $5.94 \%$ & - & - & 786,574 & $4.77 \%$ \\
\hline $\mathbf{J}$ - Financial intermediation & Financial services & 35,645 & $0.27 \%$ & - & - & 35,645 & $0.22 \%$ \\
\hline $\begin{array}{l}\text { K-Renting and business } \\
\text { activities }\end{array}$ & Advertising & 176,345 & $1.33 \%$ & - & - & 176,345 & $1.07 \%$ \\
\hline $\begin{array}{l}\text { L - Public administration and } \\
\text { defence; compulsory social } \\
\text { security }\end{array}$ & Tourism related services (INATEL) & 406,500 & $3.07 \%$ & - & - & 406,500 & $2.46 \%$ \\
\hline \multirow[t]{2}{*}{$\begin{array}{l}\text { O - Other community, and } \\
\text { personal services activities }\end{array}$} & $\begin{array}{l}\text { Cultural, entertaining and sport } \\
\text { activities }\end{array}$ & 288,312 & $2.18 \%$ & 101,683 & $3.12 \%$ & 389,995 & $2.36 \%$ \\
\hline & Personal services & - & - & 195,600 & $6.01 \%$ & 195,600 & $1.19 \%$ \\
\hline Total & & $13,243,744$ & $100.00 \%$ & $3,254,128$ & $100.00 \%$ & $16,497,872$ & $100.00 \%$ \\
\hline
\end{tabular}

Legend: a) Economic Activity Classification (CAE Rev.1)

Source: Seniors' survey and INATEL (2005) Execution Report of the Programa Turismo Sénior.

tures carried out in food \& beverages services represent almost $35 \%$ of total expenditures, while only about $2 \%$ of expenditures are carried out in transports.

\section{Multiplier effects}

The degree to which a social tourism programme is an agent of economic development of a tourism destination depends, simultaneously, on the total expenditures generated and on the multiplier effects of these expenditures. The higher the destination's propensity to import, the higher will be the leakage of money flows out of the tourism destination, and, consequently, the lower will be the multipliers. Additionally, for policy and planning purposes is important to analyse how the effects of direct expenditures carried out in the scope of a social tourism programme ripple through an economy. As referred by Fletcher and Archer (1982) the concept of the multiplier is based upon the recognition that the various sectors which make up the economy are interdependent.
Table 4 presents the Keynesian multipliers of output, household income, value-added and employment of the expenditures carried out in the scope of a Portuguese social tourism programme. Keynesian multipliers, also denominated as "normal multipliers", measure the effects of an additional unit of spending carried out in consequence of the social tourism programme on a specific economic variable (e.g. output, income, employment). These multipliers can be categorized, according to the type of impacts analysed, into two groups (Miller \& Blair, 1985): (i) simple multipliers (only direct and indirect effects are accounted) and (ii) total multipliers (direct, indirect and induced effects are accounted).

The output multiplier measures the effect of an extra unit expenditure in the level of output of an economy (Archer, 1982), indicating the degree of intersectorial linkages (Lee \& Kwon, 1995). The output multipliers of the Programme show that for each euro of expenses carried out in the scope of this programme 1.693 Euros 
of output were directly and indirectly generated. When induced effects are added on, the output multiplier of the Programme increases to 4.029. These results reveal, as has been demonstrated in other studies (e.g. Lee \& Kwon, 1995), the particular importance of induced effects. Considering the products consumed in the scope of this programme, the highest output multiplier was found for accommodation and food \& beverage services (4.346), followed by tourism related services (INATEL) (4.210), while the lowest multiplier was obtained in the financial services (3.257) (Table 4).

The household income multiplier shows the relationship between an additional unit of expenditures carried out in the scope of the social tourism Programme and the consequent changes in the level of household income in the national economy. In this study, household income means personal income (corresponding to the sum of wages and salaries, mixed income, net property income, net current transfers and social benefits) as defined by the OECD (2013). For each Euro of expenditures 1.030 Euros of household income were generated. The highest household income multiplier was found for advertising services (1.147) and shopping (1.141). However, transports and travel agencies and financial sector had relatively low multiplier effects (0.816 and 0.767, respectively) (Table 4$)$.

The value-added multipliers indicate that every euro spent in the scope of the social tourism programme generated 1.398 Euros of valueadded in the national economy. The highest multipliers were found in tourism related services (1.700), advertising sector (1.553) and in the shopping sector (1.529), while the lowest value-added multipliers were obtained financial services (1.380) and in transport and travel agencies (1.231) (Table 4).

Finally, the employment multiplier reports the effect of each thousand of Euros in expenditures in full-time jobs created in the national economy. For each thousand of Euros spent in the scope of this Programme, 0.063 jobs were created. The highest employment multipliers were found in accommodation and food \& beverage services (0.074), tourism related services (0.070) and cultural,

Table 4. Multipliers effects of the Portuguese Social Tourism Programme for senior market

\begin{tabular}{|c|c|c|c|c|c|c|c|c|c|}
\hline & \multirow{3}{*}{ Types of goods and services } & \multicolumn{8}{|c|}{ Keynesian Multipliers } \\
\hline & & \multicolumn{2}{|c|}{ Output } & \multicolumn{2}{|c|}{ Household income } & \multicolumn{2}{|c|}{ Value-added (VA) } & \multicolumn{2}{|c|}{ Employment } \\
\hline & & Simple & Total & Simple & Total & Simple & Total & Simple & Total \\
\hline G & Shopping & 1.566 & 4.156 & 0.637 & 1.141 & 0.840 & 1.529 & 0.035 & 0.065 \\
\hline $\mathrm{H}$ & Accommodation and Food \& Beverage & 1.815 & 4.346 & 0.623 & 1.115 & 0.759 & 1.432 & 0.045 & 0.074 \\
\hline I & Transports and Travel Agencies & 1.560 & 3.301 & 0.428 & 0.767 & 0.768 & 1.231 & 0.018 & 0.038 \\
\hline $\mathbf{J}$ & Financial services & 1.405 & 3.257 & 0.456 & 0.816 & 0.888 & 1.380 & 0.016 & 0.037 \\
\hline K & Advertising & 1.511 & 4.115 & 0.640 & 1.147 & 0.861 & 1.553 & 0.024 & 0.054 \\
\hline $\mathrm{L}$ & Tourism related services (INATEL) & 1.270 & 4.210 & 0.720 & 1.300 & 0.920 & 1.700 & 0.030 & 0.070 \\
\hline $\mathrm{O}$ & $\begin{array}{l}\text { Cultural, entertaining and sport } \\
\text { activities and personal services }\end{array}$ & 1.539 & 4.083 & 0.626 & 1.121 & 0.806 & 1.482 & 0.037 & 0.066 \\
\hline & $\begin{array}{l}\text { Resulting from expenditures generated } \\
\text { to implement the Programme }\end{array}$ & 1.703 & 3.987 & 0.562 & 1.007 & 0.770 & 1.377 & 0.035 & 0.061 \\
\hline & $\begin{array}{l}\text { Resulting from extra-programme } \\
\text { expenditures carried out by seniors }\end{array}$ & 1.650 & 4.199 & 0.627 & 1.123 & 0.808 & 1.485 & 0.038 & 0.068 \\
\hline & $\begin{array}{l}\text { Resulting from the totality of } \\
\text { expenditures }\end{array}$ & 1.693 & 4.029 & 0.574 & 1.030 & 0.777 & 1.398 & 0.036 & 0.063 \\
\hline
\end{tabular}


entertaining and sport activities and personal services (0.066). Again, the lowest employment multiplier effects were obtained in transports and travel agencies (0.038) and financial services (0.037) (Table 4).

A global analysis of the multipliers effects of the Portuguese social tourism programme for the senior market (Table 4) permits the conclusion that the multiplier effects resulting from extraprogramme expenditures carried out by seniors are higher than the multiplier effects resulting from expenditures undertaken to implement the Programme. These differences are related to different structures of consumption. Additionally, shopping, accommodation, food \& beverage services and tourism related as well as cultural/ entertaining services have higher multiplier effects, appearing to have stronger linkage effects than other sectors. The results of this study are similar to those of other studies on the economic impact of tourism (e.g. Lee \& Kwon; Kim \& Chon, 2009).

In order to analyse the relevance of secondary effects (indirect plus induced) versus primary (direct) effects of the social tourism programme, Table 5 presents a disaggregation of multipliers effects. These results show that secondary effects of this Programme are higher than primary effects, corroborating the results obtained in other studies (e.g. Archer, 1995; Lee \& Know, 1995; Eusébio et al., 2013b). For example, for output multipliers the secondary effects were three times larger than primary effects.

\section{Total economic benefits}

In this study the total economic benefits of the Portuguese social tourism programme were estimated multiplying the expenditures carried out in the scope of this Programme by multipliers for output, household income, valueadded and employment. As shown in Table 6, $16,497.872$ Euros of expenditures carried out in the scope of this programme generated 66, 468,995 Euros of output, being only $24 \%$ generated directly. The total expenditures also generated 16,985,570 Euros of household income and 23,063,389 Euros of value-added, being $34 \%$ of household income and $32 \%$ of value-added generated directly. The total receipts generated by this Programme created
Table 5. Disaggregation of the multipliers effects of the Portuguese Social Tourism Programme for senior market

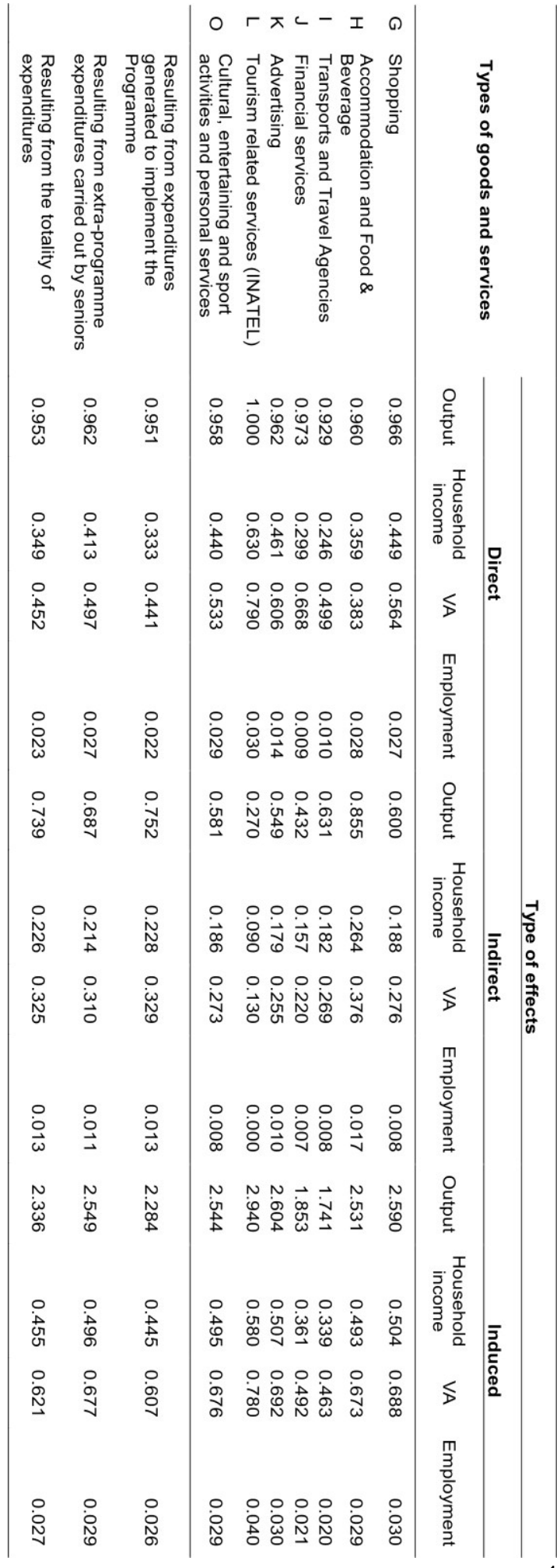


about 1,034 full-time jobs, being 379 generated directly. As far as economic activities that directly benefit from this Programme are concerned, the accommodation and food \& beverage sectors generated the largest impact in all economic variables (output, household income, value-added and employment) analysed, followed, in a second position, by the transports and travel agencies and, thirdly, by local commerce.

The results estimated for the economic impact of the Portuguese social tourism programme for the senior market was found to be substantial to the Portuguese economy, when all impacts (direct, indirect and induce effects) were accounted. These results confirm the important role of this Programme in the economic revitalization of tourism destinations and, consequently, for the stimulation of the country's economy.

\section{Conclusions and implications}

Social tourism for seniors is becoming increasingly relevant due to many factors such as population ageing, social exclusion as well as financial and health barriers the senior population is facing. There is evidence of benefits regarding health, social inclusion, wellness and overall well-being of tourism practice in general and for the elderly in particular. Social tourism initiatives for seniors can already be found in some countries. Several researchers and international associations consider that social tourism programmes may provide great benefits both to the participants of these programmes and to the destinations where these programmes take place. However, there is a lack of research in this field, mainly concerning the economic relevance of social tourism initiatives for the economic development of destinations.

This paper analyses the economic impacts of a Portuguese social tourism programme for seniors - coordinated by the INATEL Foundation - on the host communities using two complementary approaches: (i) the analysis of the perceptions of tourism suppliers regarding the referred impacts, based on the results of a questionnaire survey; and (ii) the quantification of the direct, indirect and induced economic benefits of the Programme, based on the direct expenditures made by the INATEL Foundation and on the amount of money spent by the seniors who participated in the Programme.

The results of the first approach reveal that tourism suppliers perceive positive benefits of the Programme on their own organizations and even more important benefits on the local

Table 6. Total economic benefits of the Portuguese Social Tourism Programme for senior market

\begin{tabular}{|c|c|c|c|c|c|c|c|c|c|c|}
\hline \multicolumn{3}{|c|}{ Total benefits } & $\begin{array}{c}\text { G - } \\
\text { Shopping }\end{array}$ & $\begin{array}{c}\mathrm{H}- \\
\text { Accommodation } \\
\text { and Food \& } \\
\text { Beverage }\end{array}$ & $\begin{array}{c}\text { I- } \\
\text { Transports } \\
\text { and Travel } \\
\text { Agencies }\end{array}$ & $\begin{array}{c}\mathrm{J}- \\
\text { Financial } \\
\text { Services }\end{array}$ & $\begin{array}{c}\mathrm{K}- \\
\text { Advertising }\end{array}$ & $\begin{array}{c}\mathrm{L}- \\
\text { Tourism } \\
\text { and related } \\
\text { services }\end{array}$ & $\begin{array}{l}\text { O - Cultural, } \\
\text { entertaining } \\
\text { and sport } \\
\text { activities }\end{array}$ & Total \\
\hline \multirow{16}{*}{ 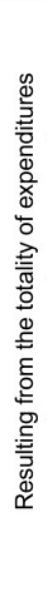 } & \multirow{4}{*}{ 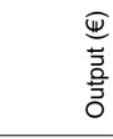 } & Direct & 1710065 & 8750504 & 4095427 & 34683 & 169644 & 406500 & 561000 & 15727822 \\
\hline & & Indirect & 1062970 & 7793212 & 2780887 & 15383 & 96842 & 109755 & 340300 & 12199350 \\
\hline & & Induced & 4584673 & 23071841 & 7675469 & 66046 & 459124 & 1195110 & 1489559 & 38541823 \\
\hline & & Total & 7357709 & 39615557 & 14551783 & 116111 & 725610 & 1711365 & 2390860 & 66468995 \\
\hline & \multirow{4}{*}{ 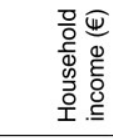 } & Direct & 794844 & 3272324 & 1084473 & 10658 & 81295 & 256095 & 257662 & 5757350 \\
\hline & & Indirect & 332751 & 2402156 & 803325 & 5586 & 31626 & 36585 & 108708 & 3720737 \\
\hline & & Induced & 892722 & 4492218 & 1494493 & 12859 & 89394 & 235770 & 290026 & 7507483 \\
\hline & & Total & 2020317 & 10166698 & 3382290 & 29103 & 202315 & 528450 & 656396 & 16985570 \\
\hline & \multirow{4}{*}{ 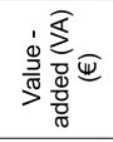 } & Direct & 998423 & 3491086 & 2199804 & 23811 & 106865 & 321135 & 312122 & 7453247 \\
\hline & & Indirect & 489033 & 3426278 & 1187298 & 7833 & 44967 & 52845 & 159657 & 5367911 \\
\hline & & Induced & 1218473 & 6131434 & 2039831 & 17552 & 122014 & 317070 & 395858 & 10242231 \\
\hline & & Total & 2705929 & 13048798 & 5426933 & 49196 & 273846 & 691050 & 867637 & 23063389 \\
\hline & \multirow{4}{*}{ 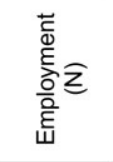 } & Direct & 47.80 & 255.22 & 44.08 & 0.32 & 2.47 & 12.20 & 16.98 & 379.07 \\
\hline & & Indirect & 14.68 & 152.93 & 35.21 & 0.24 & 1.77 & 0.00 & 4.60 & 209.42 \\
\hline & & Induced & 52.80 & 265.70 & 88.39 & 0.76 & 5.29 & 16.26 & 17.15 & 446.35 \\
\hline & & Total & 115.27 & 673.85 & 167.69 & 1.32 & 9.52 & 28.46 & 38.74 & $1,034.84$ \\
\hline
\end{tabular}


community of the host destination. Those perceiving higher benefits on their organizations are the managers of organizations where INATEL expenditures are highest - accommodation, transportation companies and restaurants - whereas those who perceive higher benefits on the local communities are the managers of entertainment companies and restaurants, who are more likely to be integrated in the referred communities. The results of the second approach show that the increase of the goods and services demand generated by both the seniors participating in the Programme and the INATEL Foundation originated significant direct, indirect and induced economic effects in the Portuguese economy, namely on output, income and employment. As far as the multipliers are concerned (output, employment, household income and value-added), it should be highlighted that the Programme's secondary effects are higher than the primary effects. This result corroborates other studies' findings that stress the importance of the tourism activity's secondary effects (e.g. Archer, 1995; Lee \& Know, 1997).

One of the main contributions of the study presented in this paper is the methodological approach adopted to analyse the economic impacts of a social senior tourism programme, using the two complementary approaches mentioned above. Actually, no studies are known that use this type of methodology, but it would certainly be useful in other contexts, namely to evaluate the economic impact of other social tourism programmes. Another important contribution consists in providing relevant information that may be used to define policies concerning social tourism development. Hence, as the results point out, it is important to continue developing this type of programmes given the economic benefits they produce in the organizations involved, in the destination communities and for the entire Portuguese economy.

The study also suggests that tourism suppliers are likely to have different perceptions on the economic impacts of social tourism programmes. In the case of the programme analysed, it is important to emphasize its benefits to the local economy among the suppliers found to be less aware of them. The creation of networks among tourism suppliers participating in these programmes and even between them and other local stakeholders is most relevant, since it may increase the awareness about the benefits of the programmes on tourism destinations, while eventually stimulating additional linkages inside these destinations.

This kind of study is also crucial to understand the different types of effects of the expenditures in different economic activities and, consequently, to identify the consumptions that should be more stimulated in order to increase the economic impacts of these initiatives. In this context, the results of the present study suggest that it is of utmost importance to encourage the consumption of accommodation and food \& beverage establishments in social tourism programmes since these activities showed the highest multipliers effects of the programme under analysis, contributing most to the growth of the Portuguese economy as a result of the Programme. Also shopping, tourism related and cultural/ entertainment activities show interesting multiplier effects revealing a relevant role for enhancing the economic contribution of the here analysed programme on the local and national economy. This should alert INATEL managers to continue developing initiatives integrating diverse activities and opportunities in their programmes and to eventually try to involve also those local stakeholders more actively in the planning process that are not directly serving as participants of the programme, but directly benefitting from it and which also contribute to the overall tourist experience quality and global economic impact of the programme (e.g. through regular information on the programmes' schedules, inclusion of promotional material in information kits given to programme participants, etc.). Some assumptions of the input-output model used should be considered as limitations of the study, such as the constant returns to scale production function, no input substitution and no supply constraints considered here. In order to overcome these assumptions it would be appropriate to quantify the impacts using General Equilibrium Models. The use of this methodology was not possible in this research 
due to limitations regarding the data available for the Portuguese economy. In this context, it is useful to consider other methodologies to quantify impacts in future studies. The use of several methodologies will permit the comparison of results obtained and to infer about the relevance of the different methods.

Another limitation of the study is that the economic impacts of the programme were only assessed for one year (2005). Although this may be a limitation of this paper, the aims of this research are to highlight the relevance of developing social tourism initiatives and present a possible framework, which encompasses both qualitative and quantitative approaches, that may be used in future studies designed to assess the impact of social tourism initiatives. This kind of studies is of utmost importance in countries such as Portugal where, traditionally, there was a strong support to these initiatives, through public funds, but where this support tends to decrease, mainly due to the economic crisis. However, it is on periods of economic crises and population ageing that this kind of social initiatives assumes particular relevance in order to ensure "tourism for all". The Portuguese programme under analysis has been suffering some changes in the last years, namely a decrease of public funds. It was considered particularly important to carry out this research in a period where the social initiatives were having a great dynamic, involving a high number of seniors and receiving a strong government support, to better emphasise the relevance of this kind of social tourism initiatives. In order to extend knowledge in this field, where there is hardly any research, it is recommended to carry out longitudinal studies to understand the evolution of the impacts of the initiative analysed. It would also be very interesting to apply the here proposed methodology to assess the economic impacts of social tourism programs in other contexts, namely in other countries and for other target publics.

Acknowledgment: This paper was developed based on a study carried out by researchers of the University of Aveiro for the INATEL Foundation concerning the socioeconomic impacts of the "Programa Turismo Sénior".

\section{References}

Almeida, M. V. (2011) The development of social tourism in Brazil. Current Issues in Tourism 14 (5), 483-489.

All-Party Parliamentary Group on Social Tourism (2011) Giving Britain a Break: Inquiry into the Social and Economic Benefits of Social Tourism. URL: http://appgonsocialtourism.nationbuilder.co $\mathrm{m}$ (Accessed on 15.03.2014).

Andereck, K. L., K. M. Valentine, R. C. Knopf, C. A. Vogt (2005) Residents' Perceptions of Community Tourism Impacts. Annals of Tourism Research 32 (4), 1056-1076.

Archer, B. H. (1982) The value of multipliers and their policy implications. Tourism Management 3, 236-241.

Archer, B. (1995) The impact of international tourism on the economy of Bermuda, 1994. Journal of Travel Research 34 (2), 27-30.

Baaijens, S. R., P. Nijkamp, K. V. Montfort (1998) Explanatory meta analysis for the comparison and transfer of regional tourist income multipliers. Regional Studies 32, 839-849.

Bélanger, C. E., L. Jolin (2011) The International Organisation of Social Tourism (ISTO) working towards a right to holidays and tourism for all. Current Issues in Tourism 14 (5), 475-482.

Bergstrom, J. C., H. K. Cordell, G. A. Ashley, A. E. Watson (1990) Economic impacts of recreational spending on rural areas: A case study. Economic Development Quarterly 4 (1), 29-39.

BITS (2011) URL: http://www.bits-int.org/ (Accessed on 15.02.2011).

Byrd, E. T., H. E. Bosley, M. G. Dronberger (2009) Comparisons of stakeholder perceptions of tourism impacts in rural eastern North Carolina. Tourism Management, 30, 693-703.

Carneiro, M. J., C. Eusébio, E. Kastenholz, H. Alvelos (2013b) Socioeconomic Impacts of Health Tourism: An Analysis of a Portuguese Programme. In Joukes, V., L. L. Gomes, A. M. Costa (ed.) (2013). Sustainable Medical and Wellness Destination: Client-, Result- and Innovation - Focused Case Studies. Vila Real: Universidade de Trás-os-Montes e Alto Douro, 46-59. 
Carneiro, M. J., C. Eusébio, E. Kastenholz, H. Alvelos (2013) Motivations to participate in social tourism programmes: a segmentation analysis of the senior market. Anatolia: An International Journal of tourism and Hospitality Research 24 (3), 352-366.

Cleaver, M., T. E. Muller (2002) I want to pretend I'm eleven years younger: subjective age and seniors' motives for vacation travel. Social Indicators Research 60 (1-3), 227-241.

Daniels, M. J., W. C. Horman, M. S. Henry (2004) Estimating income effects of sport tourism event. Annals of Tourism Research 31 (1), 180-199.

Daniels, M. J., W. C. Norman, M. S. Henry (2004) Estimating income effects of a sport tourism event. Annals of Tourism Research 31 (1), 180-190.

Dann, G. (2002) Senior Tourism and Quality of Life. Journal of Hospitality \& Leisure Marketing 9 (1-2): 5-19.

Diekmann, A., S. McCabe (2011) Systems of social tourism in the European Union: a critical review. Current Issues in Tourism 14 (5), 417-430.

Dwyer, L., P. Forsyth, R. Spurr (2005) Estimating the impacts of special events on economy. Journal of Travel Research 43, 351-359.

EESC (2006) Opinion of the European Economic and Social Committee on social tourism in Europe. Brussels: EESC- Official Journal of the European Union, 23rd December 2006.

EUROSTAT (2012) Population projections. URL: http://epp.eurostat.ec.europa.eu/ statistics_explained/index.php/Population_p rojections (Accessed on 04.03.2014).

EUROSTAT (2013) Key figures on Europe 2013 digest of the online Eurostat yearbook. URL: http://epp.eurostat.ec.europa.eu/cache /ITY OFFPUB/KS-EI-13-001/EN/KS-EI-13001-EN.PDF (Accessed on 04.03.2014).

Eusébio C., E. A. Castro, C. Costa (2013b) The Economic Impact of Tourism in the Central Region of Portugal: A Regional Economic Impact Study with Marketing Implications. In Tisdell, C. A. (ed.) (2013) Handbook of Tourism Economics: Analysis, New Applications and Case Studies. London: World Scientific, 543-572.
Eusébio, C., M. J. Carneiro (2012) Sociocultural impacts of tourism in urban destinations. Revista Portuguesa de Estudos Regionais 30 (1), 65-76.

Eusébio, C., M. J. Carneiro, E. Kastenholz, H. Alvelos (2013a) The Economic Impact of Health Tourism Programmes. In Matias, A., P. Nijkamp, M. Sarmento (ed.) (2013) Quantitative Methods in Tourism Economics. Lisbon: Physica-Verlag, 153174.

Fleischer, A., A. Pizam (2002) Tourism constraints among Israeli seniors. Annals of Tourism Research 29 (1), 106-123.

Fontanari, M., A. Kern (2003) The "comparative analysis of spas" - an instrument for the repositioning of spas in the context of competition in spa and health tourism. Tourism Review 58 (3), 20-28.

Frechtling, D.C., E. Horváth (1999) Estimating the multiplier effects of tourism expenditures on a local economy through a regional input-output model, Journal of Travel Research 37, 324-332.

Fresenmair, D. R., L. Jones, S. Um, T. Jr. Ozuna (1989) Assessing the economic impact of outdoor recreation travel to the Texas Gulf Coast. Journal of Travel Research 28 (1), 18-23.

González, A. M., C. Rodríguez, M. R. Miranda, M. Cervantes (2009) Cognitive age as a criterion explaining senior tourists' motivations. International Journal of Culture, Tourism and Hospitality Research 3 (2), 148-164.

Hardy, A. (2005) Using Grounded Theory to Explore Stakeholder Perceptions of Tourism. Journal of Tourism and Cultural Change 3 (2), 108-133.

Hazel, N. (2005) Holidays for children and families in need: An exploration of the research and policy context for social tourism in the UK. Children and Society 19, 225-236.

Higgins-Desbiolles, E. (2006). More than an "industry": The forgotten power of tourism as a social force. Tourism Management 27, 1192-1208.

Hjerpe, E. E., Y-S. Kim (2007) Regional economic impacts of Grand Canyon River Runners. Journal of Environmental Management 85, 137-149 
INATEL (2005) Execution Report of the Programa Turismo Sénior 2005, Lisboa: INATEL.

INE (2007). Contas anuais definitivas (base 2000) - 2003. Instituto Nacional de Estatística: Lisboa

Kim, S. S., K. Chon (2009) An economic impact analysis of the Korean exhibition industry. International Journal of Tourism Research 11, 311-318.

Kumar, N. P. (2004) Economic impact of tourism on Fiji's economy: empirical evidence from the computable general equilibrium model. Tourism Economics 10 (4), 419-433.

Lee, C., K. Kwon (1995) Importance of secondary impact of foreign tourism receipts on the South Korean Economy. Journal of Travel Research 34 (2), 50-54.

Lichty, R. W., D. N. Steines (1982) Measuring the impact of tourism on a small community, Growth and Change 13 (2), 36-39.

Liu, J., Turgut, V., \& Timur, A. (1984). Tourismincome multipliers for Turkey. Tourism Management, 5, 280-287.

Magnus, G. (2009) The Age of Ageing. Singapore: John Wiley.

Mayen, M., M. Muller, M. Woltering, J. Arnegger, H. Job (2010) The economic impact of tourism in six German national parks. Landscape and Urban Planning 92 (2), 73-82.

McCabe, S., S. Johnson, S. (2013) The happiness factor in tourism: subjective wellbeing and social tourism. Annals of Tourism Research 41 42-65.

McCabe, S. (2009) Who needs a holiday? Evaluating social tourism. Annals of Tourism Research 36 (4), 667-688.

McCabe, S., T. Joldersma, C. Li (2010) Understanding the benefits of social tourism: Linking participation to subjective well-being and quality of life. International Journal of Tourism Research 12 (6), 761773
Miller, R. E., P. D. Blair (1985) Input-Output Analysis: Foundations and Extensions. Englewood Cliffs, NJ: Prentice Hall.

Minnaert, L., R. Maitland, G. Miller (2007) Social tourism and its ethical foundations. Tourism Culture \& Communication 7, 7-17

Minnaert, L., R. Maitland, G. Miller (2011) What is social tourism? Current Issues in Tourism 14 (5), 403-415.

Minnaert, L., R. Maitland, G. Miller (2009) Tourism and social policy: The value of social tourism, Annals of Tourism Research 36 (2), 316-334.

Nimrod, G. (2008) Retirement and tourism Themes in retirees' narratives. Annals of Tourism Research 35 (4), 859-878.

Nimrod, G., A. Rotem, (2010) Between relaxation and excitement: activities and benefits in retirees' tourism. International Journal of Tourism Research 12 (1), 65-78.

OECD (2013) URL: http://www.oecdilibrary.org/sites/factbook-2013en/03/01/02/index.html?itemld=/content/cha pter/factbook-2013-23-en (Accessed on 04.03.2014).

United Nations (1948) General Assembly Resolution 217 A, Paris: United Nations.

Urhausen, J. (2008) Tourism in Europe: does age matter? Industry, trade and services. EUROSTAT- Statistics in focus, 69/2008. URL: http://epp.eurostat.ec.europa.eu/portal/page /portal/product_details/publication?p produc $\mathrm{t}$ code=KS-SF-08-069. (Accessed on 04.03.2014).

Wang, K-C., J. Chen, S-H. Chou (2007) Senior tourists' purchasing decisions in group package tour, Anatolia 18 (1), 23-42.

West, G. R (1993) Economic significance of tourism in Queensland. Annals of Tourism Research 20 (3), 490-504. 